RESEARCH ARTICLE

\title{
Papaw fruit juice as source for single cell protein production using natural palmyrah toddy yeast
}

\author{
Sarathadevi Rajendran ${ }^{1, *}$, Ranganathan Kapilan ${ }^{2}$ and Seevaratnam Vasantharuba ${ }^{1}$ \\ ${ }^{1}$ Department of Agricultural chemistry, University of Jaffna, Jaffna, Sri Lanka \\ ${ }^{2}$ Department of Botany, University of Jaffna, Jaffna, Sri Lanka
}

Received:16/05/2018; Accepted:14/07/2018

\begin{abstract}
The study was carried out to perform Liquid State Fermentation (LSF) to produce Single Cell Protein (SCP) from papaw (Carica papaya) fruit juice using natural yeast obtained from Palmyrah (Borassus flabellifer) toddy. The LSF was performed in a shaking incubator $(100 \mathrm{rpm})$ with the control fermentation medium (glucose) inoculated with $5 \mathrm{~mL}$ toddy. The glucose and $\left(\mathrm{NH}_{4}\right)_{2} \mathrm{SO}_{4}$ of the control medium were replaced with $100 \mathrm{ml} / \mathrm{L}$ of papaw fruit juice. The fermentation time, temperature and different concentrations of carbon and nitrogen sources on the SCP production were determined. After optimizing the conditions, the fermentation was carried out for 72 hours at $30^{\circ} \mathrm{C}$ with $5 \%$ of papaw fruit juice, and this has significantly increased the SCP yield to $40 \%$ crude protein from $35.5 \%$ (1.13 times). When the papaw juice was supplemented with inorganic nutrient supplements $\left(\mathrm{KH}_{2} \mathrm{PO}_{4}, \mathrm{MgSO}_{4} .7 \mathrm{H}_{2} \mathrm{O}, \mathrm{CaCl}_{2}\right.$ and $\left.\mathrm{NaCl}\right)$, the crude protein content was significantly $(\mathrm{p}<0.05)$ increased to $43.1 \%$ from $40 \%$ (1.08 times). After the reduction of nucleic acid using $1 \mathrm{~N} \mathrm{NaOH}$, the crude protein yield increased further by $1 \%$ (from $43.1 \%$ to $44.1 \%$ ). When the medium was supplemented with nitrogen sources such as soybean flour, groundnut flour, corn flour, ammonium sulphate and peptone, no significant changes were determined. The amino acid analysis of the crude protein indicated that the product contained all the essential amino acids. Vitamin B analysis of SCP revealed that the crude protein contained thiamin $(0.81 \mathrm{mg} / 100 \mathrm{~g})$ and riboflavin $(2.3 \mathrm{mg} / 100 \mathrm{~g})$. Therefore, the production of crude protein from papaw fruit juice with natural toddy yeast culture could be used as a more economical method of producing SCP efficiently. This method can be further expanded in order to apply in industries.
\end{abstract}

Keywords: Liquid state fermentation (LSF), papaw fruit juice, single cell protein (SCP), palmyrah toddy, yeast.

\section{INTRODUCTION}

The ever increasing world population also requires an increase in food supply. The food protein shortage worldwide has become a concern at present. Increased protein demand led to the search for new and cheap protein supplements than conventional protein sources. Single Cell Protein (SCP) is one of the solutions suggested to meet the global protein demand. The SCP refers to dead, dry microbial cells which includes proteins, lipids, carbohydrates, nucleic acids, minerals and vitamins but most part of cell comprising proteins (Ware, 1977).
SCP has been produced from different microorganisms like algae, fungi, yeast and bacteria. These microorganisms utilize inexpensive carbon sources for the growth and production of bio protein. They also show the ability to upgrade low quality protein food into high quality protein food. SCP generally has high nutritive value due to higher content of proteins, vitamins and essential amino acids (Galvez et al., 1990). However, it may also have some nutritive issues like high nucleic acid content that may lead to slower digestion and some allergic reactions to humans (Anupama et al., 2000 and Ugbogu et al., 2016). If SCP is to be used successfully as a protein rich food, there are some criteria to be satisfied. Of which, the most important one being that SCP should contain high protein content with essential amino acids. Further, it should contain less than $2 \%$ of nucleic acids and the production is economical. SCP has been produced from capsicum powder (Zhao et al., 2009), pineapple waste (Dhanasekaran et al., 2011), sugarcane bagasse (Rao et al., 2010 and Samadi et al., 2016), papaya extract (Maragatham et al., 2011), orange and cucumber peel (Mondal et al., 2012), cassava starch (Tipparat et al., 1995), wheat straw (Abou et al., 1993), date waste (Mohamed et al., 2012), mango waste (Rashad et al., 1990), chinese potato (Anbuselvi et al., 2015), coconut waste water (Smith et al., 1976), banana waste (Saquido et al., 1981), apple waste (Khan et al., 2010) and vegetable oils (Mihaela et al., 2012). It is also known that organisms such as Candida utilis, Saccharomyces cerevisiae, Penicillium janthinellum and Candida tropicalis can produce SCP (Nasseri et al., 2011).

Papaw (Carica papaya) is an important fruit crop belonging to the family Caricaceae. Papaw is cultivated throughout the island and produce fruits year around. Papaw fruits contain high carbon content and less protein content (Miller et al., 1936). Palmyrah (Borassus flabellifer) toddy is a naturally available source containing diverse yeast species. Endogenous micro flora of toddy is not only composed of natural yeast but also contains less number of acetic acid and lactic acid producing bacteria (mixed-culture of toddy). The main aim of this study was to identify a cheap and an easy method of producing SCP using natural and cost-effective sources. In the study, papaw fruit juice and yeast of palmyrah toddy were used as 
the medium and the inoculums respectively to optimize the culture growing and fermentation conditions to increase the yield.

\section{MATERIALS AND METHODS}

\section{Strains and media}

Papaw fruits (variety- 'Red lady') were obtained from a local market at Thirunelvelly, Jaffna, Sri Lanka. Palmyrah toddy was directly obtained from a tapper during the period from March to May in 2017. Palmyrah toddy was collected from matured trees under required conditions (time evening $4.00-5.00 \mathrm{pm}$. and temperature $28-30^{\circ} \mathrm{C}$ ) using sterile vessels and this was used as the source of natural yeast.

\section{Preparation of Papaw fruit juice}

Ripened papaw fruits were washed with sterile water and peeled to remove the skin. Seeds were removed from sliced pulp and the pulp was macerated in a blender (National, MX-795N) for 5 minutes. The fruit juice was filtered with the use of a Muslin cloth. The juice extracted was placed in a steriled glass container and autoclaved at $121^{\circ} \mathrm{C}$ and 15 psi for 15 minutes.

\section{Preparation of the medium and fermentation}

Papaw and control (Glucose) media were prepared according to the following composition (Control: D-Glucose - $10.0 \mathrm{~g}, \mathrm{KH}_{2} \mathrm{PO}_{4}-1.0 \mathrm{~g},\left(\mathrm{NH}_{4}\right)_{2} \mathrm{SO}_{4}-5 \mathrm{~g}$, $\mathrm{MgSO}_{4} \cdot 7 \mathrm{H}_{2} \mathrm{O}-0.5 \mathrm{~g}, \mathrm{NaCl}-0.1 \mathrm{~g}, \mathrm{CaCl}_{2}-0.1 \mathrm{~g}$ and distilled water 1,000 mL, Papaw based medium: papaw juice - 100 $\mathrm{mL}, \mathrm{KH}_{2} \mathrm{PO}_{4}-1.0 \mathrm{~g}, \mathrm{MgSO}_{4} .7 \mathrm{H}_{2} \mathrm{O}-0.5 \mathrm{~g}, \mathrm{NaCl}-0.1 \mathrm{~g}$, $\mathrm{CaCl}_{2}-0.1 \mathrm{~g}$ and distilled water $900 \mathrm{~mL}$ ).

Each medium was transferred into steriled bottles and autoclaved at $121^{\circ} \mathrm{C}$ and $15 \mathrm{psi}$ for 15 minutes. Then 50 $\mathrm{mL}$ of each medium was filled into six $250 \mathrm{~mL}$ Erlenmeyer flasks in triplicates. In each flask, $5 \mathrm{~mL}$ of natural toddy was added under sterile condition (microbial count $2.0405^{*} 10^{6}$ \pm 2500 viable cells $/ 1 \mathrm{~mL}$ ). The inoculated flasks were placed in a shaking incubator (JEIO TECH, SJ-600) at 100 rpm. After completion of each batch of fermentation, the fermented liquid was poured into centrifuge tubes and they were centrifuged at 4,000 rpm for 20 minutes (Mondal et al., 2012). Sediment was collected and oven-dried at 50 ${ }^{\circ} \mathrm{C}$ for 16 hours. Dry weight was measured and protein estimation was done according to the method of Kjeldahl (AOAC International.2006). Crude protein value was expressed as $\mathrm{N}^{*} 6.25$.

\section{Single cell protein production from papaw juice}

Protein content of papaw fruit juice was initially determined using Kjeldahl method. Papaw only medium (papaw juice - $100 \mathrm{~mL}$ and distilled water $900 \mathrm{~mL}$ ) was used in $250 \mathrm{~mL}$ of Erlenmeyer flasks. The flasks were inoculated with $5 \mathrm{~mL}$ of natural toddy under sterile conditions. Fermentation was allowed for 24 hours at $28^{\circ} \mathrm{C}$ in a shaking incubator $(100$ $\mathrm{rpm}$ ). Crude protein content was determined by Kjeldahl method.

\section{Optimization of culture conditions for SCP production}

\section{Optimization of Fermentation time}

Papaw medium (10\% concentration) was allowed to ferment with $5 \mathrm{~mL}$ of natural palmyrah toddy in Erlenmeyer flasks with three replicates $(250 \mathrm{~mL})$ at $28^{\circ} \mathrm{C}$ in a shaking incubator $(100 \mathrm{rpm})$. Samples were taken from the flasks after 1, 2, 3, 4, 5, 7 days of fermentation and the crude protein contents were determined using the Kjeldahl method (Samadi et al., 2016).

\section{Optimization of fermentation temperature}

Fermentation was carried out with papaw medium (10\% concentration) at different temperatures such as 25,28 , 30,35 and $40^{\circ} \mathrm{C}$ using $5 \mathrm{~mL}$ of natural palmyrah toddy in Erlenmeyer flasks $(250 \mathrm{~mL})$. Fifteen samples were taken after three days of fermentation and the crude protein contents were determined.

\section{Effect of different concentrations of carbon source in fermentation medium on SCP production}

Fermentation was carried out with different concentrations of papaw sole medium $(1,2,3,4,5,10,20,50$ and $100 \%$ concentration of sole medium) at $30^{\circ} \mathrm{C}$ using five $\mathrm{mL}$ of natural palmyrah toddy in Erlenmeyer flasks $(250 \mathrm{~mL})$. Twenty seven samples were taken after three days of fermentation and thecrude protein contents were measured (Babu et al., 2017).

\section{Reduction of nucleic acid}

Reduction of nucleic acid from microbial cells with $\mathrm{NaOH}$ was done (Herbert et al., 1971). $20 \mathrm{ml}$ of $1 \mathrm{~N} \mathrm{NaOH}$ was added to $5 \mathrm{~g}$ of dried microbial biomass. Removal of nucleic acid was performed in a boiling water bath for 10 minutes. After cooling to room temperature $\left(28.5^{\circ} \mathrm{C}\right)$, the solution was centrifuged and sediment was oven dried and the crude protein was determined.

\section{Effect of different nitrogen sources on SCP production}

Medium was added with different types of edible flour (corn flour, soybean flour, groundnut flour), $\left(\mathrm{NH}_{4}\right)_{2} \mathrm{SO}_{4}$ and peptone $(5 \mathrm{~g} / \mathrm{L})$ with papaw medium $(5 \%$ juice concentration) and $5 \mathrm{~mL}$ of natural palmyrah toddy was added to Erlenmeyer flasks $(250 \mathrm{~mL})$ in triplicate and allowed for fermentation. Eighteen samples were taken after three days at $30^{\circ} \mathrm{Cand}$ the crude protein contents were determined.

\section{Determination of amino acid composition}

Fermentation was carried out with $5 \%$ papaw juice medium at $30^{\circ} \mathrm{C}$ using $5 \mathrm{~mL}$ of natural palmyrah toddy in Erlenmeyer flasks $(250 \mathrm{~mL})$. Samples were taken from shaking incubator after three days of fermentation and the protein yield was subjected for amino acid analysis. One $\mathrm{mg}$ of SCP biomass was hydrolyzed using $6 \mathrm{~N} \mathrm{HCl}$ for $22 \mathrm{~h}$ at $110^{\circ} \mathrm{C}$ and finally suspended in $1 \mathrm{mM} \mathrm{HCl}$ (Fountoulakis et al., 1998). Amino acid composition was analyzed using an auto amino acid analyzer. 


\section{Determination of Vitamin B}

SCP yield from the media after 3 days of fermentation was analyzed for Vitamin B composition such as thiamin and riboflavin using HPLC. Microbial dry biomass $(2 \mathrm{~g})$ was hydrolyzed using $0.1 \mathrm{~N} \mathrm{H}_{2} \mathrm{SO}_{4}$ for 30 minutes at $121^{\circ} \mathrm{C}$. Then it was adjusted to $\mathrm{pH} 4.5$ with $2.5 \mathrm{M}$ sodium acetate. After that $50 \mathrm{mg}$ Takadiastase enzyme was added. Then, the mixture was filtered through a Whatman No. 4 filter and the filtrate was diluted with $50 \mathrm{~mL}$ of pure water and filtered again through a micro pore filter $(0.45 \mu \mathrm{m})$. Twenty microliters of the filtrate was injected into the HPLC system. Quantification of vitamin B content was accomplished by comparison to vitamin B standards (Sami et al., 2014).

\section{Cost analysis}

Cost analysis was done in order to produce 100 gram of SCP from papaw fruit juice as a sole medium, addition of inorganic nutrients and after reduction of nucleic acid from SCP.

\section{Statistical analysis}

All experiments were carried out in triplicate and the graphs were expressed as mean value of the data. Experimental design was a Completely Randomized Design (CRD) and statistical analysis (ANOVA) was done using the SAS8 statistical package. The means were compared using Duncan's Multiple Range Test (DMRT at $0.05 \alpha$ ).

\section{RESULTS AND DISCUSSIONS}

\section{Protein and nitrogen analysis of fresh papaw fruit juice}

Protein and nitrogen contents of papaw fruit juice were determined. Amount of protein available in the papaw fruit juice was rather low $(1.25 \pm 0.065 \%)$. Total nitrogen content was also low $(0.2 \pm 0.01 \%)$.

\section{Single cell protein production from papaw juice}

Crude protein content obtained after one day of fermentation at $28^{\circ} \mathrm{C}$ was $35.4 \pm 0.12 \%$. This indicates that the toddy yeast could be used to produce relatively higher concentration of protein with papaw juice as the medium with no addition of other nutrient supplements. In order to increase the crude protein content, different culture growth conditions were used.

\section{Optimization of culture conditions for SCP production}

In order to increase the SCP content from papaw fruit juice, it was fermented using mixed culture of yeasts obtained from palmyrah toddy. The culture growing conditions such as fermentation time, incubating temperature, concentration of carbon source, reduction of nucleic acid and addition of different nitrogen sources to the fermentation media were optimized in order to improve the SCP production.

\section{Fermentation time on protein production}

Fermentation time is one of the key factors that influence the protein production within microbial cells (Jamal et al., 2008, Samadi et al., 2016). The result of this study is summarized in figure 1. Amount of crude protein produced was significantly higher on the $3^{\text {rd }}$ day of fermentation (Control - $39.3 \%$, papaw medium - $42.0 \%$ ). Amount of crude protein produced showed an increasing trend with the increasing fermentation time from the first day to 3 days for both the media (control and papaw medium). Anyhow after 3 days of fermentation, crude protein content showed a reducing trend because of the limited availability of nutrients and reduction of carbon source in the medium during lengthened fermentation, probably impact on microbial cells to consume the produced protein (Samadi et al., 2016).Similar observations have been reported, in an experiment carried out with sugarcane bagasse using yeast (Samadi et al., 2016) and with pineapple waste using yeast (Dhanasekaran et al., 2011). In another study using Candida utilis, higher SCP yield was obtained after 54 hours of fermentation with Sabouraud glucose agar medium (Babu et al., 2017).

\section{Fermentation time on biomass production}

The dry biomass was increased with the increase in fermentation time. Biomass production was highest on the $7^{\text {th }}$ day of fermentation in both papaw and control media (Figure 2). The biomass production through fermentation of papaw juice was significantly higher $(0.51 \mathrm{~g})$ than the control (0.389 g). Similar results were also obtained in an experiment carried out with sugarcane bagasse (Samadi et al., 2016) in a tray bioreactor and with pineapple waste using yeast as the inoculums (Dhanesekaran et al., 2011). Since the maximum crude protein yield was obtained on the $3^{\text {rd }}$ day of the fermentation (Figure 1), the 3-day duration was selected as the fermentation time in further studies.

\section{Effect of fermentation temperature}

Temperature of the fermentation medium is one of the major parameters which affect the protein production in microbial cells (Walsh, 1977). Crude protein production was lower (Control - $36.3 \%$, papaw medium - $34.1 \%$ ) at $40^{\circ} \mathrm{C}$ whereas it was higher (Control $-40.3 \%$, papaw medium $-42.7 \%$ ) at $30^{\circ} \mathrm{C}$ (Figure 3). The optimum temperature for growth of yeast (Saccharomyces cerevisiae) had been reported to be active in the range of $30-35^{\circ} \mathrm{C}$ (Walsh, 1977). Therefore, $30^{\circ} \mathrm{C}$ was used as the temperature for further studies. Similar observation was noted by Babu et al., (2017) with Sabouraud glucose agar medium using Candida utilis at $30^{\circ} \mathrm{C}$. At higher temperatures (at $40^{\circ} \mathrm{C}$ ), SCP yield was lower and this may be due to the partial inactivation of enzymes which involved in metabolic reaction in microbial cells (Samadi et al., 2016).

\section{Effect of concentration of carbon sources}

Figure 4 depicts the influence of different concentrations of papaw juice as the sole medium for single cell protein production. The highest concentration of crude protein was obtained at 5\% papaw juice. Babu et al., 2017 recorded the maximum protein content with Candida utilis at 5\% sugarcane bagasse as the medium. The crude protein content increased with increasing fruit juice concentrations from $1 \%$ to $5 \%$, followed by a decrease due to the substrate suppressive effect. The results suggest that organisms 


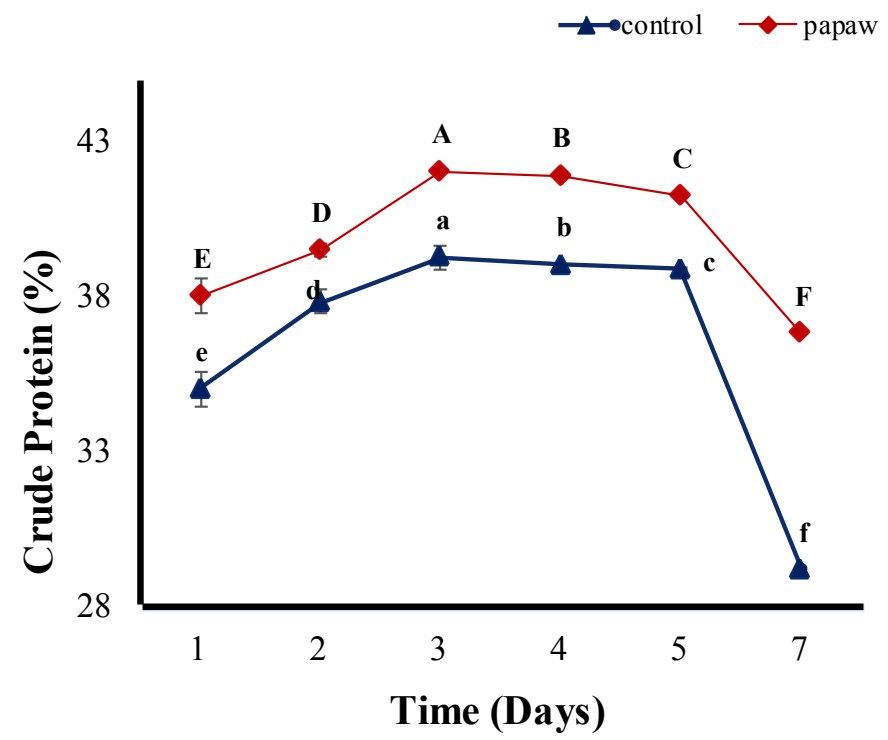

Figure 1: Effect of fermentation time on SCP production from toddy mixed culture at $28^{\circ} \mathrm{C}$, under the liquid fermentation system. Mean significant differences were tested for control and papaw medium using DMRT at $\alpha$ level 0.05. Capital letters indicated significant difference between means of crude protein of papaw medium at different fermentation days. Small letters indicated significant difference between means of crude protein of control medium at different fermentation days.

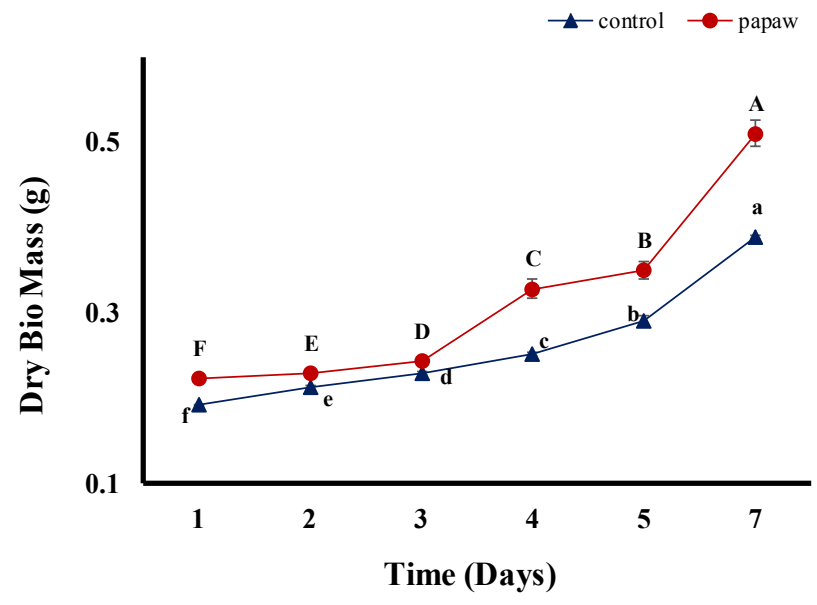

Figure 2: Effect of fermentation time on dry biomass production from toddy mixed culture at $28^{\circ} \mathrm{C}$, under the liquid fermentation system. Mean significant differences were tested for control and papaw medium using DMRT at $\alpha$ level 0.05. Capital letters indicated significant difference between means of dry biomass content of papaw medium at different fermentation days. Small letters indicated significant difference between means of dry biomass content of control medium at different fermentation days.

found in toddy (yeast, lactic and acetic acid bacteria) are capable of grow in fruit juices without supplementation of inorganic nutrients, which could make SCP production more costly.

After the optimization (temperature, time and concentration of carbon sources), the amount of crude protein increased to $40 \%$ from $35.5 \%$ (1.13 times). The amount of crude protein increased to $43.1 \%$ when other nutrient supplements were added except the nitrogen source $\left(\mathrm{KH}_{2} \mathrm{PO}_{4}, \mathrm{MgSO}_{4} .7 \mathrm{H}_{2} \mathrm{O}, \mathrm{CaCl}_{2}\right.$ and $\left.\mathrm{NaCl}\right)$ (Table-1). The results indicated that toddy microorganisms efficiently utilized inorganic nutrient supplements in order to produce a higher SCP. Similar observation was also recorded with orange and cucumber peel extracts with glucose supplemented fruit hydrolysates and yeast (Mondal et al., 2012).

\section{Effect of reduction of nucleic acid for higher SCP production}

Reduction of nucleic acids by the addition of $1 \mathrm{~N} \mathrm{NaOH}$ caused significant changes in the SCP production. When the nucleic acid was reduced using $1 \mathrm{~N} \mathrm{NaOH}$, the amount of crude protein content was increased by $1 \%$ (from $44.0 \%$ from $43.1 \%$ ) (Table 2 ). Similar observation was recorded with single cell protein produced by Penicillium janthinellum using sugarcane bagasse as the medium (Rao et al., 2010). Increase of crude protein when the nucleic acid content decreased could be explained by the removal of protein adhered with nucleic acid. 


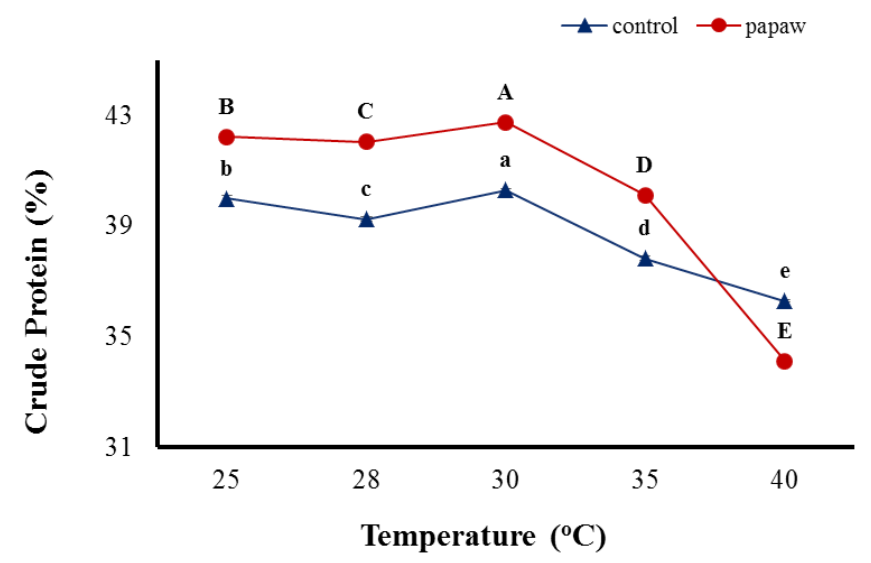

Figure 3: Effect of fermentation temperature on SCP production from toddy mixed culture in 3 days of fermentation time, under the liquid fermentation system. Mean significant differences were tested for control and papaw medium using DMRT at $\alpha$ level 0.05 . Capital letters indicated significant difference between means of crude protein of papaw medium atdifferent temperatures. Small letters indicated significant difference between means of crude protein of control medium at different temperatures.

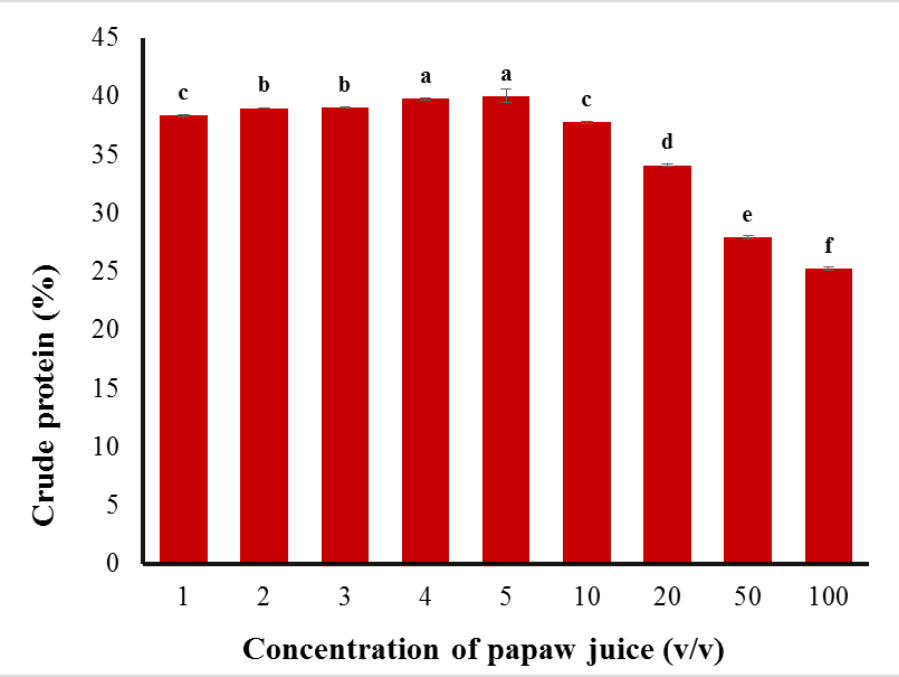

Figure 4: Effect of different concentrations of papaw juice sole medium on SCP production from toddy mixed culture in 3 days of fermentation at $30^{\circ} \mathrm{C}$, under the liquid fermentation system. Mean significant differences were tested using DMRT at $\alpha$ level 0.05. Same letters indicated no significant differences between means.

Table 1: Crude protein content after optimization of culture growing conditions.

\begin{tabular}{ccc}
\hline & \multicolumn{2}{c}{ Crude protein (\%) } \\
\hline & before optimization & $\begin{array}{c}\text { after } \\
\text { optimization }\end{array}$ \\
\hline Papaya medium & $40^{\mathrm{b}} \pm 0.076$ & $43.12^{\mathrm{a}} \pm 0.044$ \\
\hline
\end{tabular}

Values are the means \pm standard error of 3 replicates.

Different superscript letters denoted significant difference between means of crude protein.

Table 2: Crude protein content after the reduction of nucleic acid from microbial cells.

\begin{tabular}{ccc}
\hline & \multicolumn{2}{c}{ Crude protein (\%) } \\
\hline & before nucleic acid removal & after nucleic acid removal \\
\hline papaw & $43.12^{\mathrm{b}} \pm 0.044$ & $44.05^{\mathrm{a}} \pm 0.029$ \\
\hline
\end{tabular}

Values are the means \pm standard error of 3 replicates.

Different superscript letters denoted significant difference between means of crude protein. 


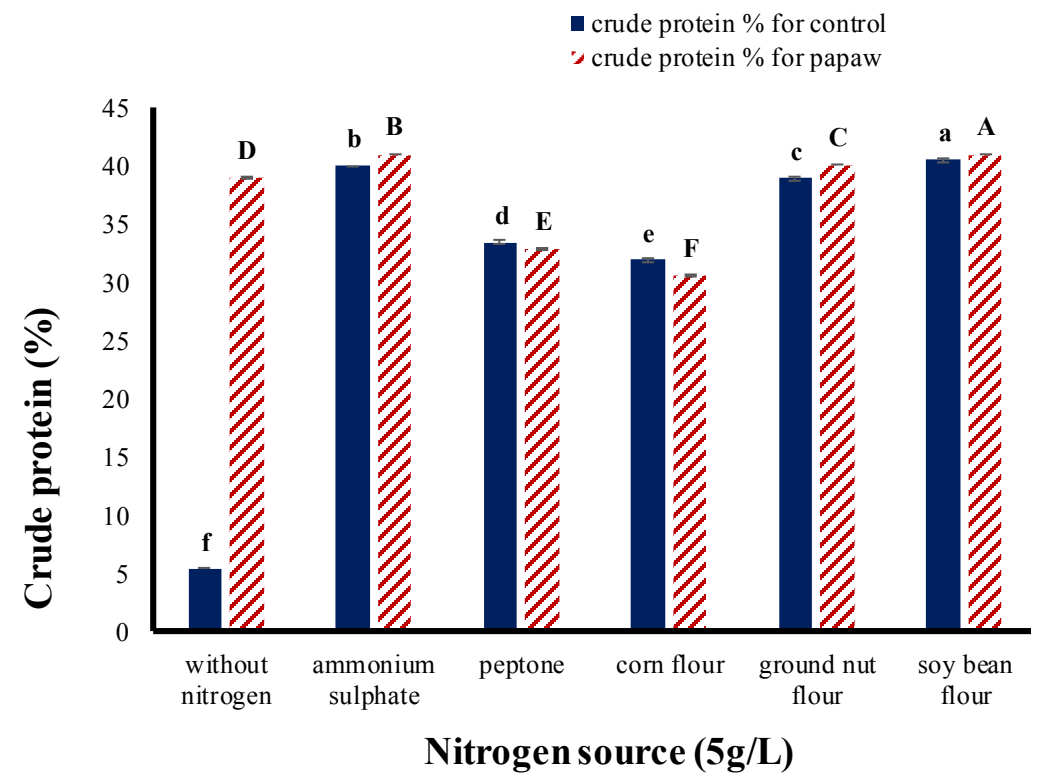

Figure 5: Effect of different nitrogen sources on SCP production from mixed culture of yeast for 3 days of fermentation at $30^{\circ} \mathrm{C}$ under the liquid fermentation system. Mean significant differences were tested for control and papaw medium using DMRT at $\alpha$ level 0.05 . Capital letters indicated significant difference between means of crude protein of papaw medium at different nitrogen sources. Small letters indicated significant difference between means of crude protein of control medium at different nitrogen sources.

\section{Effect of different nitrogen sources in fermentation medium on SCP production}

The influence of nitrogen source on SCP production is given in Figure 5. When organic and inorganic nitrogen sources are added using locally available sources such as soybean flour, corn flour and ground nut flour, peptone and ammonium sulphate, the highest crude protein yield was obtained with soya bean flour $(41.25 \%)$. In favour, the amount of crude protein produced was significantly low when corn flour was used $(30.55 \%)$ in papaw juice. The SCP production showed no significant differences with different nitrogen sources as papaw juice itself contained enough nitrogen for microbial growth.

\section{Amino acid composition}

The amino acid composition of SCP produced from 5\% liquid papaw fruit juice is summarized in the Table 3 . The protein contains almost all the essential amino acids and some non-essential amino acids. Among these amino acids, methionine, arginine, valine and tryptophan were found in higher concentrations than the rest and phenyl alanine, threonine and lysine were relatively low. In comparison to FAO standards and soybean amino acids as a reference (Carrera et al., 2011), SCP contained a higher concentration of methionine. Lysine and valine contents were higher in the SCP produced by Penicillium janthinellum using sugarcane bagasse as the medium (Rao et al., 2010). Amount of valine and tyrosine were higher than the other amino acids in the SCP produced from sugarcane bagasse using Saccharomyces cerevisiae (Samadi et al., 2016).

\section{Vitamin B composition}

The analysis of Vitamin B of SCP produced from 5\% liquid papaw fruit juice revealed the presence of thiamin and riboflavin (Table 4). Other vitamin B components were either absent or at a trace levels in the extracted SCP. Thiamin and riboflavin were also reported in SCP produced from dextrose medium using Candida tropicalis (Chandrani et al., 2000).

Following the optimization of the culture growth conditions and media composition and the reduction of nucleic acids from microbial cells, the SCP production was increased from 35.45 to $44.05 \%$ (1.243 times) in the present study.

\section{Cost Analysis}

When only papaw fruit juice was used as the medium, the cost for the production of $100 \mathrm{~g} \mathrm{SCP}$ was LKR 108.00, indicating a cost effective method of SCP production using papaw fruit juice and Palmyrah toddy. Therefore, SCP can be effectively used as a protein supplementation in pace of high cost conventional protein foods. When papaw medium is supplemented with other nutrients $\left(\mathrm{NaCl}, \mathrm{CaCl}_{2}\right.$ and $\mathrm{MgSO}_{4}$ ), the cost for $100 \mathrm{~g} \mathrm{SCP}$ was LKR 128.00. The reduction of nucleic acid from SCP could increase the production costs by 1.22 times. 
Table 3: Amino acids composition (\% dry matter) obtained from SCP produced from papaw fruit juice as mediumduring auto amino acid analysis.

\begin{tabular}{lccc}
\hline \multicolumn{1}{c}{ Amino acids } & Amount (\% dry matter) & Soybean & FAO standard \\
\hline Lysine $^{*}$ & $0.2^{\mathrm{c}}$ & $2.37^{\mathrm{b}}$ & $4.2^{\mathrm{a}}$ \\
Tryptophan $^{*}$ & $2.2^{\mathrm{a}}$ & - & - \\
Threonine* $^{\mathrm{a}}$ & $0.1^{\mathrm{b}}$ & - & $2.8^{\mathrm{a}}$ \\
Methionine * & $3.2^{\mathrm{a}}$ & $0.59^{\mathrm{c}}$ & $2.2^{\mathrm{b}}$ \\
Valine * & $2.2^{\mathrm{b}}$ & $1.94^{\mathrm{c}}$ & $4.2^{\mathrm{a}}$ \\
Isoleucine $^{*}$ & $1.1^{\mathrm{b}}$ & $1.97^{\mathrm{a}}$ & - \\
Leucine * & $1.8^{\mathrm{c}}$ & $3.47^{\mathrm{b}}$ & $4.8^{\mathrm{a}}$ \\
Glutamate & $0.6^{\mathrm{b}}$ & $8.14^{\mathrm{a}}$ & - \\
Phenylalanine* & $0.1^{\mathrm{c}}$ & $2.25^{\mathrm{b}}$ & $2.8^{\mathrm{a}}$ \\
Histidine* & $0.9^{\mathrm{b}}$ & $1.05^{\mathrm{a}}$ & - \\
Arginine & $2.4^{\mathrm{b}}$ & $2.91^{\mathrm{a}}$ & - \\
\hline
\end{tabular}

Essential amino acids are denoted as*

Different superscript letters denoted significant difference between means of particular amino acid content row wise.

Table 4: Thiamin and Riboflavin content of SCP from papaw juice (mg/100g).

\begin{tabular}{cc}
\hline & Papaw medium \\
\hline Thiamin & 0.81 \\
Riboflavin & 2.3 \\
\hline
\end{tabular}

Table 5: Cost of $100 \mathrm{~g} \mathrm{SCP}$ production from papaw fruit juice medium.

\begin{tabular}{ll}
\hline & Papaw (Rs.) \\
\hline Price of $1 \mathrm{~kg}$ fruit & 80 \\
Cost for $100 \mathrm{~g} \mathrm{SCP}$ production from $1 \mathrm{~kg}$ fruit & 83 \\
Other charges including Palmyrah toddy and labour cost for $100 \mathrm{~g} \mathrm{SCP}$ production & 25 \\
Total cost to produce $100 \mathrm{~g} \mathrm{SCP}$ from sole papaw juice medium & 108 \\
Cost of inorganic nutrients $\left(\mathrm{NaCl}, \mathrm{CaCl}_{2,} \mathrm{MgSO}_{4)}\right.$ & 20 \\
Cost of NaOH to reduce nucleic acid content from SCP & 28 \\
Total cost for $100 \mathrm{~g} \mathrm{SCP}$ production after addition of nutrients in the medium and reduction & 156 \\
of nucleic acids & \\
\hline
\end{tabular}

\section{CONCLUSION}

The present findings revealed that papaw fruit juice and natural toddy can be used as an effective combination of a carbon source and an inoculants to produce SCP containing all essential amino acids and some of vitamin $\mathrm{B}$ components including thiamin and riboflavin.

\section{ACKNOWLEDGEMENTS}

Authors wish to express their sincere gratitude to the University of Jaffna for providing the financial support to undertake this study.

\section{REFERENCES}

Abou, H.S.A.A. (1993). Bioconversion of wheat straw by yeast into single cell protein. Egyptian Journal of Microbiology. 28(1):1-9.

Anbuselvi, S., Avinash, and Manas, J. (2015). Optimization of single cell protein from Chinese potato by submerged fermentation.Der Pharmacia Lettre.7(4):281-283.

Anupama and Ravindra, P. (2000). Value added Food: single cell protein. Biotechnology advances. 18:459479.https://doi.org/10.1016/s0734-9750 (00)00045-8. 
AOAC: The Association of Official Analytical Chemists. The Official Methods of Analysis of AOAC International, 18th ed. Arlington, 2006. U.S.A.

Babu, M.P. and Ilyas, M.H.M. (2017). SCP production from Candida utilis isolated from velar estuary. International Journal of Advanced Research in Biological Sciences. 4(1):34-43. https://doi.org/10.22192/ ijarbs.2017.04.01.004.

Carrera, C.S., Reynoso, C.M., Funes, G.J., Martínez, M.J., Dardanelli, J. and Resnik, S.L. (2011). Amino acid composition of soybean seeds as affected by climatic variables. Pesquisa Agropecuaria Brasileir. 46(12): 1579-1587.

Chandrani, S. and Jayathilake, A.N. (2000). Characteristics of two yeast strains (Candida tropicalis) isolated from Caryota urens (kithul) toddy for single cell protein production. Journal of National Science Foundation Sri Lanka. 28(1):79-86. https://doi.org/10.4038/jnsfsr. v28i1.2936.

Dhanasekaran, D., Lawanya, S., Saha, S., Thajuddin, N. and Panneerselvam, A. (2011). Production of single cell protein from pineapple waste using yeast. Innovative Romanian Food Biotechnology. 8:26-32.

Fountoulakis, M. and Lahm, H.W. (1998). Hydrolysis and amino acid composition analysis of proteins. Journal of Chromatography. 826:109-134. https://oi. org/10.1016/s0021-9673 (98)00721-3.

Galvez, A., Ramirez, M.Z. and Garcia, G.M. (1990). Chemical composition of a mixture of single cell protein obtained from Kluyveromyces fragilis and whey proteins. National Center for Biotechnology Information. 40(2):252-62.

Herbert, D., Phipps, P.J. and Strange, R.E. (1971). Chemical analysis of microbial cells, in: Methods in Microbiology. 5:244-249. https://doi.org/10.1016/ s0580-9517 (08)70641-X.

Jamal, P., Alam, M.Z. and Salleh, N.U. (2008). Media optimization for bio proteins production from cheaper carbon source. Journal of Engineering Science and Technology. 3(2):124-130. https://doi.org/10.1007/9783-540-69139-6_219

Khan, M., Khan, S.S., Ahmed, Z. and Tanveer, S. (2010). Production of Single Cell Protein from Saccharomyces cerevisiae by utilizing Fruit Wastes. NanobiotechnicaUniversale. 1(2):95-178.

Maragatham, C. and Panneerselvam, A. (2011). Production of single cell protein from yeast using papaya extract medium. Advances in Applied Science Research. 2:1418.

Mihaela, B., Alexandrina, S., Yannis, K. and Romulus, D. (2012). Single cell protein production of Candida strains in culture media based on vegetable oils. Romanian Biotechnological letters. 17(6):7776-7786.

Miller, C.D. and Robbins, R.C. (1937). The nutritive value of papaya. Biochemical Journal. 31(1):1-11.

Mohamed, A., Alaa, A.B., Hassan, A.M. and Thomas, R. (2012). Production of single cell protein from date waste.Abu Dhabi Food Control Authority Development Sector Research \& Development Division. 1(1):1-7.

Mondal, A.K., Samadrita, S., Jayati, B. and Bhattacharya, D.K. (2012). Utilization of fruit wastes in producing single cell protein. International Journal of Science, Environment. 1(5):430-438.

Morton, J.F. (1988). The palmyrah or toddy palm (Borassus flabellifer L.). Economic botany. 42(3): 420-441.https:// doi.org/10.1007/bf02860166

Nasseri, A.T., Morowvat, M.H., Amini, R.S. and Ghasemi, Y. (2011). Single cell protein: production and process. American journal of food technology. 6(2):103-116. https://doi.org/10.3923/ajft.2011.103.116

Rao, M., Varma, A.J. and Deshmukh, S.S. (2010). Production of single cell protein, essential amino acids, and xylanase by Penicillium janthinellum. Bioresources Journal. 5 (4):2470-2477.

Rashad, M.M., Moharib, S.A. and Jwanny, E.W. (1990). Yeast conversion of mango waste or methanol to SCP and other metabolites. Biological Wastes.32(4):277-284. https://doi.org/10.1016/0269-7483 (90)90059-2

Samadi, S., Mohammadi, M. and Najafpour, G.D. (2016). Production of single cell protein from sugarcane bagasse by Saccharomyces cerevisiae in tray bioreactor. International Journal of Engineering. 29:1029-1036. https://doi.org/10.5829/idosi.ije.2016.29.08b.01

Sami, R., yang, L., Baokun, Q., Wang, S., Zhang, Q., Feifei, H., Ying, M., Jing, J. and Jiang, L. (2014). HPLC Analysis of water soluble vitamins and fat soluble vitamins of okra. Journal of Chemistry. 1-6. https://doi. org/10.1155/2014/831357.

Saquido, P.M.A., Cayabyab, V.A. and Vyenco, F.R. (1981). Bioconversion of banana waste into SCP. Journal of Applied Microbiology \& Biotechnology. 5(3):321-326.

Smith, M.E. and Bull, A.T. (1976). Protein and other compositional analysis of Saccharomyces fragilis grown on coconut water waste. Journal of Applied Bacteriology Banner. 41:97-107. https://doi. org/10.1111/j.1365-2672.1976.tb00609.x

Tipparat, H. and Aran, H. (1995). Optimization of single cell protein production from cassava starch using Schwanniomyces castellii.World Journal of Microbiology \& Biotechnology. 11:607-609. https:// doi.org/10.1007/bf00360999

Ugbogu, E.A. and Ugbogu, O.C. (2016). A review of microbial protein production: prospects and challenges. FUW Trends in Science and Technology Journal. 1 (1):182-185.

Walsh, R.M. (1977). Growth of Saccharomyces cerevisiae and Saccharomyces uvarum in temperature gradient incubator.Journal of the institute of brewing. 83:169-172. https://doi.org/10.1002/j.2050-0416.1977.tb06813.x.

Ware, S.A. Single cell protein and other food recovery technologies from waste, municipal environmental research laboratory, Office.

Zhao, G., Zhang, W. and Zhang, G. (2009). Production of single cell protein using waste capsicum powder produced during capsanthin extraction. The Society of Applied Microbiology. 50(2):187-191. https://doi. org/10.1111/j.1472-765x.2009.02773.x. 